\title{
The (No-)Impact of the Arms Embargo on the Relations between the European Union and China
}

\author{
Asst. Prof. Dr. Armağan Gözkaman (Beykent University, Turkey)
}

\begin{abstract}
The present study focuses on the relations between China and the European Union by taking into consideration a specific matter of discord: The arms embargo, which is effective since 1987 and which has political and economic repercussions. Chinese authorities have frequently asked for the removal of the embargo, but the European authorities declined despite internal divisions. Nevertheless, commercial relations between Brussels and Beijing grow bigger and no deterioration is expected in the foreseeable future. The objective of the study is to find the reasons why the embargo may still remain in place. The reason why European authorities stick to the ban is threefold. First, their arms sales to China can lead to a shift in the balance of power with undesired consequences. Second, the European Union is backed by major powers (especially Japan and the USA) on the issue. Third, the current stalemate has not impeded the development of political and economic relations between Beijing and Brussels so far.
\end{abstract}

\section{Introduction}

Relations between the European Union and China have always been based upon political considerations (widely shaped by the human rights issue) and economic interests. The former aspect of these relations have come to fore by the brutal repression of the student-led popular demonstrations in 1989. The Chinese government's choice led to widespread international outcry. For its part, the European Community (EC) took a series of measures, beginning with an embargo on the arms sales to China, that were complemented in time by other arrangements.

Ever since, the relations between Beijing and Brussels are stained. Although successive Chinese governments reiterated their demand on the abolishment of the embargo, the European partners preferred to carry it on. There are at least three reasons why the embargo is still in place despite Chinese discontent and European divisions. The concern on a possible shift in the balance of power, foreign support brought to the European stance and the lack of a tangible impact of the embargo upon the relations between the two sides.

\section{The Arms Embargo and Its Consequences for the EU - China Relations}

In order to draw an analysis of the embargo's impact upon the relations between China and the EU, exploring two issues seems to be useful: The content of the embargo (along with the ensuing politico-juridical arrangements) and the reaction of Chinese authorities in the context of differing European approaches.

\subsection{European Decision to Ban Arms Exports to China: A Process That Has Spread to Two Decades}

At the summit that convened in Madrid on 26 and 27 June 1989, the EC's twelve member states called on the Chinese authorities to "put an end to the repressive actions against those who legitimately claim their democratic rights". They also agreed upon a number of sanctions against China including the interruption of military cooperation and an embargo on arms trading. Some of the measures had diplomatic repercussions, such as the raising of Chinese human rights questions in international fora (accompanied by the idea of demanding the expedition of independent observers with the aim of attending the trials and visiting the prisons) and the suspension of high-level meetings at ministerial level. Future cooperation projects were negatively affected by the repression of 1989 as well: They were either postponed or reduced. The twelve also exposed their willingness to postpone the examination of credit requests -both in the Community and World Bank frameworks (European Council, 1989).

The embargo did not materialize into a juridical text; instead, it was confined to a European Council declaration. This can be considered a weakness, for the member states would apply the measures agreed in 1989 in accordance with the laws and decrees that they would enact and the arrangements that they would make. On this account, it seems relevant to remind that the "the scope of the embargo [was] not clearly defined" and that the embargo did not cover "a large proportion of sensitive items" (EU Council Secretariat, 2005). It was therefore necessary to complement the declaration of embargo with a firmer formulation in order to fill its deficiencies.

The above-mentioned necessity explains the agreement of the EC member states at the Luxembourg and Lisbon European Councils of 1991 and 1992 on a series of common criteria to take into consideration while exporting armament material. There is a strong parallelism between the standards set out back then and the FivePower Guidelines for Conventional elaborated by the permanent members of the United Nations Security Council in 1991. It is also important to note that the European Union Code of Conduct on Arms Exports adopted at the European Council of June 1998 drew upon these criteria (Bromley, 2012). Hence, one can legitimately 
point to the convergence of the European Community/Union's policies of exportation in a sensitive area has developed from early 1990s on in parallel with the sensibilities in the international platform.

The European Code of Conduct takes into consideration simultaneously eight conditions. They are relative to the buyer state (respect of human rights in the domestic platform, the existence of stability within national frontiers), the political choices of the recipient government (the respect of the international law, the nature of alliances, the attitudes towards terrorism, respect of international commitments, probabilities of undesired reexportation and the diversion of national resources for armaments), international security and the security interests of the EU member states (Council of the European Union, 2005).

There are at least two points that merit attention. First, the wide extent of the Code comes out as a useful instrument for harmonizing armament exports of the EU member states. As mentioned earlier, the ban imposed in 1989 was of declaratory nature. Second, as a brief of the European Corporate Counsel Review points out, the criteria set out by the Code inspired other nations such as Canada, Australia and the central and eastern European states.

Complementary regulations, which focused on the exportation of dual-use items, have been adopted in the first decade of the $21^{\text {st }}$ century. The Regulation (EC) No 1334/2000 setting up a Community regime for the control of exports of dual-use items and technology was updated in 2009 by the Regulation 428/2009. The new text is, like its predecessor, legally binding and directly applicable within the entire territory of the European Union. It brings about two surpluses vis-à-vis the legislation that was in force before 2009: the controls on brokering activities and transit with regard to dual-use goods and the list of items controlled before granting an export license.

In time, EU member states could agree upon the requirements to meet and the procedures to follow for the exportation. The convergence of member states' positions had an important consequence: The deficiencies of the embargo imposed in 1989 have been filled by subsequent legal and political instruments. During this process, the specific declaration could find (and redefine) its meaning through the arrangements that covered the wider area of armament exportation. Nevertheless, as will be mentioned above, this trend did not lead to a consensus among the Europeans on the necessity and utility of the embargo.

\subsection{European Divisions, Chinese Reactions}

The EU cannot act as a coherent international actor and define a common stance against China on the issue of arms embargo. The lack of a common position makes it difficult for the member states to reach a consensus on lifting the arms embargo. Divergences are perceived at various levels of decision-making, from the intra-state level to the community level (Cuyckens, 2012).

Chinese statesmen have frequently asked for the removal of the embargo, but the European decision-makers declined despite internal divisions as asserted in the previous section. After China had been qualified as the EU's strategic partner in 2003, a debate on the embargo became inevitable. In such a partnership, how could Beijing accept being in a sort of black list? On the other hand, how could the Europeans ignore a very important restriction such as the arms sale within a relation that they upgraded themselves? Hence, the years 2004 and 2005 have witnessed heated debates on the issue. In December 2003, the European Council had already agreed upon reconsidering the embargo and took a similar position in 2004 by inviting the Luxembourg Presidency to work for a decision before June 2005 (European Council, 2003b \& 2004). Some European states (such as France and Germany) have positioned themselves as the proponents of this campaign.

Nevertheless, a Chinese move constituted a veritable obstacle for the above-mentioned efforts to bear fruit: The anti-secession law was adopted by the National People's Congress on March 14, 2005. The law bolstered the idea of Taiwan's reunification with mainland China by peaceful means, but the use of force was an option if Taipei were to declare its independence (BBC, 2005). First of its kind, it constituted a legal basis for the hitherto verbal threat of military intervention (Rémond, 2008). The next month, a strong majority voted in the European Parliament (EP) against the lifting of the embargo (European Parliament, 2005).

Ever since, the EP's objection persists (The Economist, 2010). Nevertheless, an institutional harmony within the EU proved difficult to reach: The High Representative of the Union for Foreign Affairs, Catherine Ashton, defends the latter by saying that the "current arms embargo is a major impediment for developing stronger EUChina co-operation on foreign policy and security matters" and that the EU "should assess its practical implication and design a way forward" (Rettman, 2010). Yet, she has failed to persuade the major pro-embargo member states of the Union (Rettman, 2011a). For their part, Herman Van Rompuy (president of the European Council) and J. Manuel Barroso (president of the European Commission) have shown their stance on the issue by defending "responsible" controls on the arms trade (Nikkei Asian Review, 2013).

China still continues to work hard on the lifting of arms embargo and is unhappy that the solution has been elusive so far (Gardner, 2012). However, since the adoption of the anti-secession law, she cannot adopt assertive policies on the matter. She seems to have understood that a favorable decision was not imminent and that it was more realistic to initially focus on other issues of importance -such as the granting of status market economy ((Rémond, 2008). 


\section{Reasons Why the Embargo Is Still in Place}

At present, there are at least three reasons why the EU preserves the ban on arms sales to China: strategic calculations, international backing and the absence of negative political and economic consequences.

\subsection{The Concern to Prevent an Arms Race in the Region}

Regional conflicts constitute a field that the European Union attaches particular importance. The European Security Strategy of 2003 identified it among the five key challenges faced by the Union (European Council, 2003a). In this context, arms export control also comes up as an important instrument. As mentioned earlier, the 1998 Code of Conduct on arms exports set up mechanisms of notification and consultation. The common position of 2008 aimed to update the Code and to reinforce the Union's export control policy (OJEU, 2008b). The Council joint action adopted the same year (which established principles and criteria for arms exports among third countries), the Council decision of 2009 which complemented it, and the ensuing Council decision of 2013 lay out further efforts undertaken by the EU (OJEU, 2008a, 2009, 2013).

The EU's arms sales to China can lead to a shift in the balance of power with undesired consequences. On this account, it should be underscored that the tension between Taiwan and mainland China creates a difficulty for the EU's decision to lift the armament ban. European arms sales to China can pave the way for a better-equipped China, which may lead to a Taiwanese reaction to reinforce its armament. The situation is all the more worrying because Taiwan may not be the only country to involve in this equation.

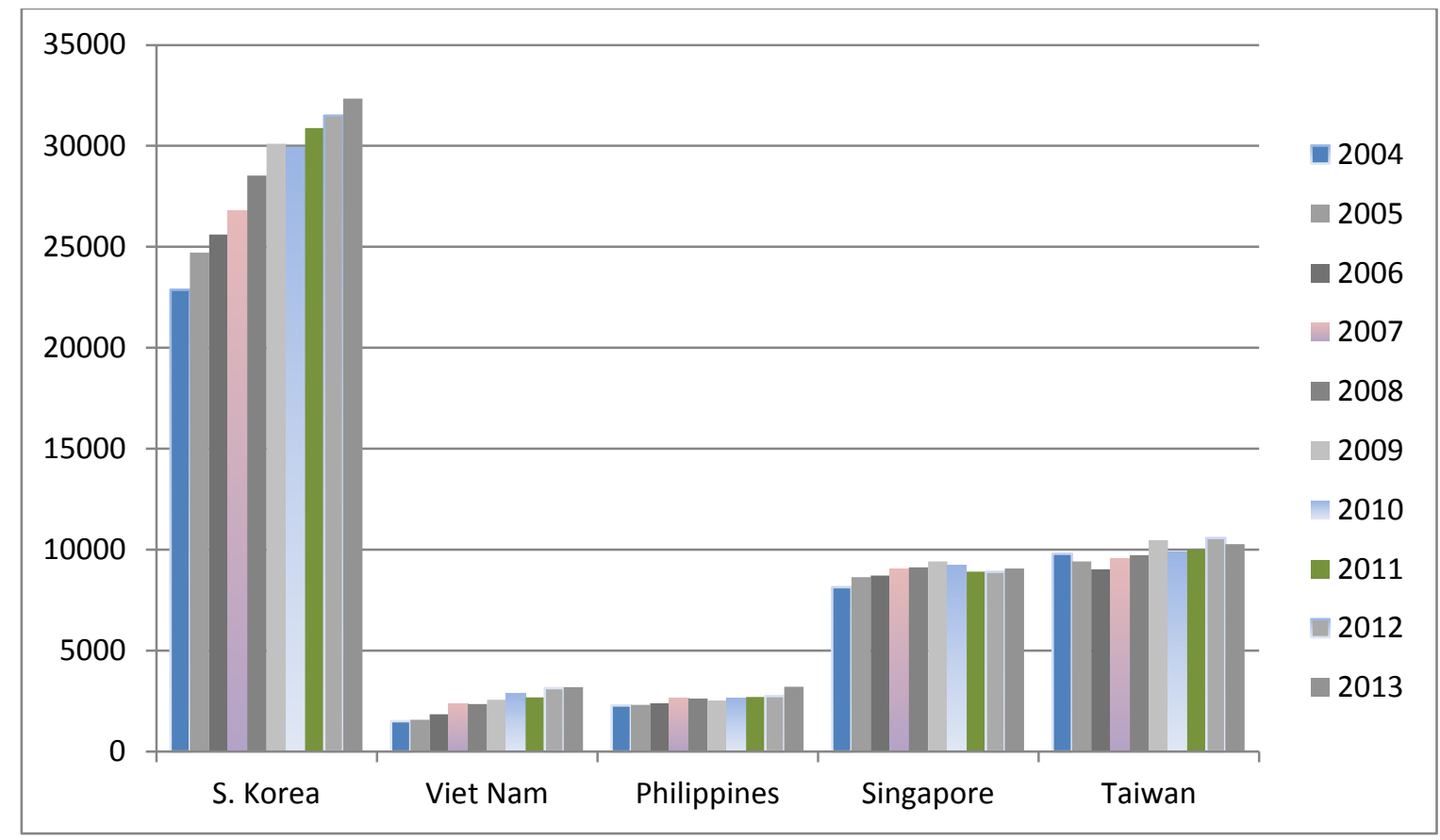

Chart 1. Trend of military expenditures in Southeast Asia in millions of dollars at constant 2011 prices and exchange rates (SIPRI Military Expenditure Database, 2014).

Numbers speak themselves and some food for thought is provided by the Chart 1. For instance, in the selected four countries of the region (South Korea, Vietnam, Philippines and Singapore), the general trend of increase observed in military expenditures may be interpreted as "alarming". This trend can be expected to continue in the future. For this reason, the European reflex of not contributing to the arms race is understandable. Increasing the fear by providing high-technology equipment to China can jeopardize the fragile stability at the region.

It is important to remind that the EU does not have super-power-type global military ambitions. As Wacker maintains, whereas the EU formulated strategy papers for all the regions of the world and set global security goals, its military and political power is mainly concentrated on its neighborhood (2011). From this point of view, the EU will not be willing to assume a gendarmerie role in every corner of the world. Yet, because it will be significantly affected by military escalation in the Taiwan Strait, it prefers not to fuel the proliferation efforts in the region.

\subsection{Foreign Support to the EU's Choice to Carry on the Ban}

The parallelism between the reactions of the EC and the US administration to the repression of Tiananmen protesters is easy to grasp. Washington considers the EU embargo rightful and wants it to stay in place; so far, it has been very influential on the prolongation of the ban. Chinese authorities are indeed unhappy about this influence (Cottey \& Gottwald, 2010). They believe that the EU should "make decisions on its own" in the future (Rettman, 2011b \& 2011c). 
On June 5, 1989, "all licenses and approvals to export defense articles and defense services" from the USA to China were suspended (Department of State, 1989). China is perceived by the United States as the biggest rival, both regionally and globally. Hence, any development likely to contribute to the accelerated modernization of the People's Liberation Army may be worrisome for American authorities. The Deputy Assistant Secretary of Defense for East Asia, Michael Schiffer, has pointed to Pentagon's possible concerns:

"The pace and scope of China's sustained military investment have allowed China to pursue capabilities we believe are potentially destabilizing to regional military balances, increase the risk of misunderstanding and miscalculation and may contribute to regional tensions and anxieties. (...) Such capabilities could increase Beijing's options to use military force to gain diplomatic advantage, advance its interests or resolve military disputes in its favor." (Keyes, 2011).

In Schiffer's opinion, the challenge posed by China is relative to the regional stability in general and to Taiwan in particular. A military confrontation in the Taiwan Strait can have severe consequences for the global economy, something that goes strongly against American interests. Besides, US troops may find themselves in a military confrontation with Chinese forces due to the pledge that was made by Washington in 1979 through the Taiwan Relations Act which paved the way for a possible US military action in the region. The section on the implementation of US policy with regard to Taiwan stipulates that "the United States will make available to Taiwan such defense articles and defense services in such quantity as may be necessary to enable Taiwan to maintain a sufficient self-defense capability". It is the responsibility of the President and the Congress to decide upon "the nature and quantity of such defense articles and services. If a threat to the security or the social or economic system of Taiwanese people arises (and, consequently, jeopardizes the interests of the US), the President and the Congress shall determine what action the US will take to meet the challenge (American Institute in Taiwan).

Within this framework, the U.S. administrations have been selling arms to Taiwan -which provoked, unsurprisingly, Chinese authorities' strong dissatisfaction and opposition. Beijing maintains that Washington should adhere to one China policy and to the three communiqués issued jointly between 1972 and 1982 . China sees the arms sales to Taiwan as an interference in its internal affairs. In Chinese view, the Taiwan question is about its territorial integrity and vital interests. Nevertheless, its strong condemnation of the USA's arms sales to Taiwan have not created an insurmountable obstacle for Beijing's relations with Washington.

The latter's considerations in exporting weaponry are multifaceted. Chinese authorities simultaneously desire to strengthen political ties, to obtain the support against strategic rivals and to gain commercial benefits (Byman and Cliss, 1999). The USA's worries are therefore threefold. First, the lifting of European embargo could improve Chinese military capabilities and strengthen Chinese superiority in the Taiwan Strait (Tang, 2005). Second, it could facilitate the transfer of military technology to the troubled regions such as Pakistan, Iran and Myanmar which are among the main clients of Beijing (Rémond, 2008). Third, it would also lead to further political advantages for China in a region to which Washington attaches a high value.

Hence, the US administrations have been against the lifting of the EU's arms embargo against China and have encouraged their traditional allies, especially Japan, to adopt a similar attitude (Rémond, 2008). Such diplomatic efforts were meant to bear fruit. In fact, Tokyo was more than ready to adopt a stance similar to that of Washington. For Japan, China's growing economic and political power and especially its highly-developed military capabilities constitute a source of concern. Governmental officials are especially preoccupied by a possible shift in the balance of the power in South East Asia. Political considerations seem to be framed in a zero-sum-game: A change in favor of China will be detrimental for Japan.

Therefore, Japanese authorities believe that although Europe's economic hardship may make the lifting of arms embargo appealing, such a decision would be a "short-sighted and dangerous" one (Swami and Moore, 2010). Japanese government's preference, especially in the context of Senkaku/Diayou islands dispute with China, will most probably be to continue its opposition to Chinese acquirement of sophisticated weaponry.

\subsection{The EU Does Not Really Need a Change in Current Circumstances}

So far, so good. The current stalemate has not impeded the development of political and economic relations so far: China has not transformed the issue into a political or military crisis. Commercial relations between Brussels and Beijing grow bigger and no deterioration is expected in the foreseeable future. As shown in the chart 1 , the EU's export towards China incessantly increased for the period 2002-2012 while its import has generally shown a trend of growth as well. For the given period, the EU's import from China has more than tripled and its export has more than quadrupled.

As exposed by the chart below, from 2002 to 2012, China's share in the EU's external trade has tended to increase as well. The rise in the EU's exportation is bigger than that of its importation. In other words, the EU has found itself in a clearly advantageous position vis-à-vis its partner. Obviously, despite the bitterness expressed by Chinese authorities on several platforms, the economic relations have not been harmed by the EU's decision not to lift the ban. 


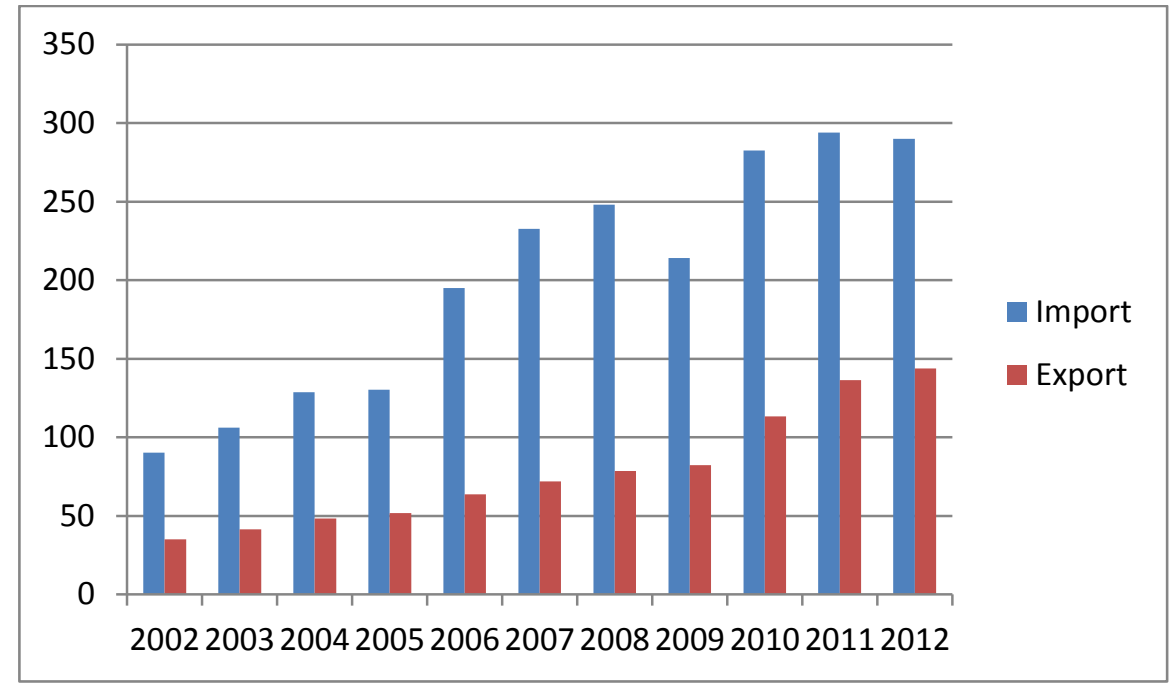

Chart 2. EU trade flows in billions of Euros between 2002 and 2012 (European Commission Directorate General for Trade, 2013).

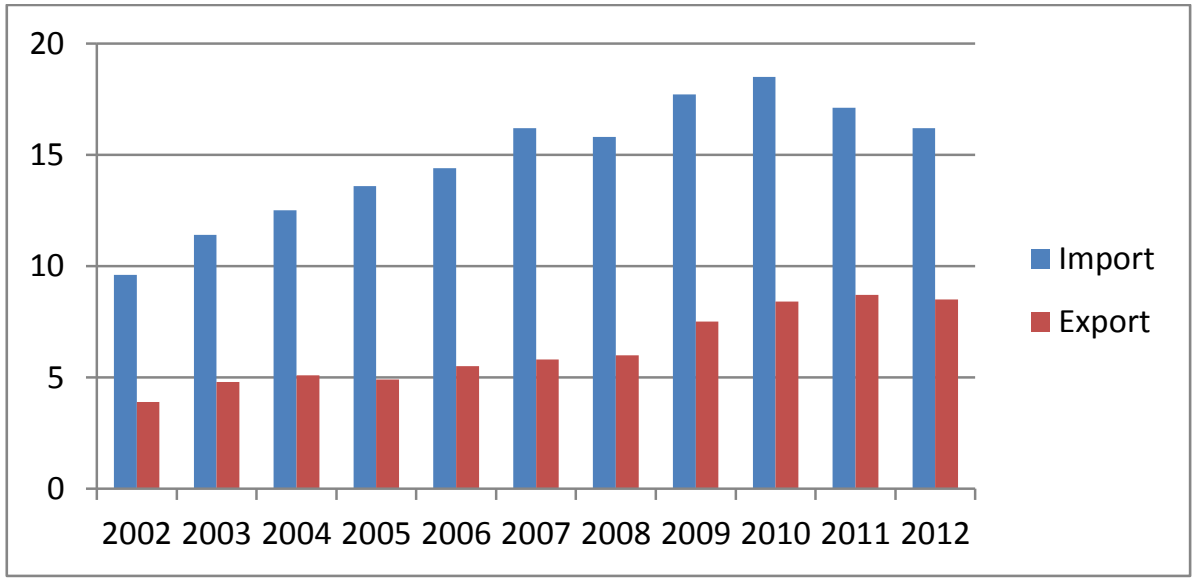

Chart 3. China's share in extra-EU trade (European Commission Directorate General for Trade, 2013).

Besides, a lifting of the embargo will most probably not result in a huge increase of arms trade. A scholar points to a number of reasons why it would not be the case (Decreton, 2009). First, because national control procedures will remain in force -they will even be strengthened through the establishment of transitional measures. Second, it is hard to expect contracts of very high value, such as a new fighter fleet or submarines because China buys them from Russia. The models supplied by Russian technology are almost as sophisticated as the ones produced by Europeans. A third reason is connected to a probability that would put China in a very difficult position in case of a conflict in the Taiwan strait: Beijing would not prefer to buy missile systems or fighter fleets from the Europeans because the latter may opt for their American ally and they may cut off the supply.

In what regards the overall cooperation between Brussels and Beijing, there is room for optimism. At the $16^{\text {th }}$ China-EU summit that took place in November 2013, an EU-China 2020 Strategic Agenda for Cooperation that covered a wide range of issues (including peace and security, prosperity, sustainable development and people-topeople exchanges) was launched (European External Action Service, 2013b). The initiative was taken as a follow-up of the EU-China Comprehensive Strategic Partnership that was built up in 2003 (European External Action Service, 2013a). Obviously, both sides value their partnership and they are willing to develop the existing cooperation schemes.

\section{Concluding remarks}

Somewhat surprisingly, the embargo did not cause a heavy damage to EU-China relations. Economic and commercial relations between the European Union (EU) and China have been growing for the last two decades. Annual summits and intermittent declarations show that political dialogue continues without interruption leading to significant economic benefits for both sides. 
The European Union has been successful in focusing on a particular event and to react against it without putting economic and political relations in jeopardy. China, after all, has a very peculiar position. It is one of the five permanent members of the UNSC, a huge market, a very important actor of the international trade and finance and a significant military power. Therefore, the relations with China are subject to careful attention. Europeans have shown that they are well aware of this reality.

One can argue that the opponents of the ban have had two important assets in fulfilling this highly delicate task. The one is connected to the support of strong allies -namely, the USA and Japan. The second asset concerns the impossibility for Beijing to insist on the abolishment of arms embargo as a consequence of the anti-secession law.

\section{References}

- American Institute in Taiwan. Taiwan Relations Act, http://www.ait.org.tw/en/taiwan-relations-act.html.

- BBC, 2005. Text of China's Anti-Secession Law, 14 March, http://news.bbc.co.uk/2/hi/asiapacific/4347555.stm.

- Byman and Cliss, 1999. China's Arms Sales: Motivations and Implications, Santa Monica, Rand Corporation, p. 7.

- Council of the European Union, 2005. European Union Code of Conduct on Arms Exports, Brussels, 5 June, p. 3-7, http://www.consilium.europa.eu/uedocs/cmsUpload/08675r2en8.pdf.

- Cottey and Gottwald, 2010. "The Current Legal Foundation and Prospective Legal Framework of the PCA" in Jing, Giuseppe, Cahiers du Collège d'Europe / College of Europe Studies: EU-China Relations in a New World Order. Status, Dynamics, Scenarios, Brussels, Peter Lang AG, p. 36.

- Cuyckens, 2012. "The EU and China: Emerging Global Powers Capable of Balancing US Hegemony and Shaping a New World Order?” in Wouters, de Wilde, Defraigne, Defraigne, China, The European Union and the Restructuring of Global Governance, Gloss \& Massachusetts, Edward Edgar Publishing, p. 302.

- Decreton, 2009. “La Question de l'Embargo sur les Ventes d'Armes à la Chine”, Critique Internationale, 43, p. 115.

- European Corporate Counsel Review. European Union Code of Conduct, http://www.fas.org/asmp/campaigns/code/eucode.html.

- European Commission Directorate-General for Trade, 2013. European Union, Trade with China, , p. 4,

- http://trade.ec.europa.eu/doclib/docs/2006/september/tradoc_113366.pdf .

- European Commission Directorate-General for Trade, 2009. Dual-Use Export Controls in the European Union (Fact Sheet), 2009, p.1, http://trade.ec.europa.eu/doclib/docs/2009/december/tradoc_145611.pdf.

- European Council, 1989. Declaration on China, Madrid, 26-27 June, p. 25, http://www.europeancouncil.europa.eu/media/848998/1989_june_-_madrid_eng_.pdf.

- $\quad$ European Council, 2003a. A Secure Europe in a Better World. European Security Strategy, Brussels, 12 December, p. 19, http://www.consilium.europa.eu/uedocs/cms_data/docs/pressdata/en/ec/78364.pdf.

- $\quad$ European Council, 2003b. Presidency Conclusions, Brussels, 12 and 13 December, p. 19, http://www.consilium.europa.eu/uedocs/cms_data/docs/pressdata/en/ec/78364.pdf.

- European External Action Service, 2013a. The EU-China Comprehensive Strategic Partnership: Working for You, Brussels, 6 November, http://eeas.europa.eu/delegations/china/documents/news/20131123.pdf.

- European External Action Service, 2013b. EU-China 2020 Strategic Agenda for Cooperation, http://eeas.europa.eu/delegations/china/documents/news/20131123.pdf.

- $\quad$ European Parliament. 2005. MEPs Reject Lifting Arms Embargo on China, April 14, http://www.europarl.europa.eu/sides/getDoc.do?pubRef=-//EP//TEXT+PRESS+DN-20050414$1+0+\mathrm{DOC}+\mathrm{XML}+\mathrm{V} 0 / / \mathrm{EN} \# \mathrm{SECTION} 4$

- European Union Council Secretariat, 2005. EU Arms and Dual Use Exports Policy and EU Embargo on China (Background), China/00 (initial), February, p. 1, https://www.consilium.europa.eu/uedocs/cmsUpload/050228_China-initial.pdf.

- Gardner, 2012. "China Criticises EU Arms Embargo”, European Voice, 20 September, http://www.europeanvoice.com/article/2012/september/china-criticises-eu-arms-embargo/75200.aspx.

- Keyes, 2011. "Pentagon Warns of Potential Problems with Militarily Strong China", CNN, 25 August, http://edition.cnn.com/2011/US/08/24/pentagon.china/.

- Nikkei Asian Review, 2013. EU to Keep Arms Embargo on China, 20 November, http://asia.nikkei.com/Politics-Economy/International-Relations/EU-to-keep-arms-embargo-on-China. 
- OJEU, 2008a. Council Joint Action 2008/230/CFSP of 17 March 2008 on Support for EU Activities in order to Promote the Control of Arms Exports and the Principles and Criteria of the EU Code of Conduct on Arms Exports among Third Countries, http://eurlex.europa.eu/LexUriServ/LexUriServ.do?uri=OJ:L:2008:075:0081:0085:EN:PDF

- OJEU, 2008b. Council Common Position 2008/944/CFSP of 8 December 2008 Defining Common Rules Governing Control of Exports of Military Technology and Equipment, http://eurlex.europa.eu/LexUriServ/LexUriServ.do?uri=OJ:L:2008:335:0099:0103:EN:PDF.

- OJEU, 2009. Council Decision 2009/1012/CFSP of 22 December 2009 on Support for EU Activities in order to Promote the Control of Arms Exports and the Principles and Criteria of Common Position 2008/944/CFSP among Third Countries, http://eurlex.europa.eu/LexUriServ/LexUriServ.do?uri=OJ:L:2009:348:0016:0020:EN:PDF.

- OJEU, 2013. Council Decision 2013/768/CFSP of 16 December 2013 on EU Activities in support of the Implementation of the Arms Trade Treaty, in the Framework of the European Security Strategy, http://eurlex.europa.eu/LexUriServ/LexUriServ.do?uri=OJ:L:2013:341:0056:0067:EN:PDF.

- Rémond, 2008. "Ventes d'Armes à la Chine: La Fin de l'Embargo Européen?”, Politique Etrangère, 2, p. 316.

- Rettman, 2010. “Ashton Pragmatic on China in EU Foreign Policy Blueprint”, EU Observer, 17 December, http://euobserver.com/china/31538.

- Rettman, 2011a. "EU to Keep China Arms Embargo despite Massive Investments", EU Observer, 5 January, http://euobserver.com/china/31592.

- Rettman, 2011b. “China: EU Bailout Leaves 'Fundamental Problems’ Unresolved”, EU Observer, 8 July, http://euobserver.com/19/32608.

- Rettman, 2011c. "Leaked Cable Shows Fragility of EU Arms Ban on China”, EU Observer, 25 July, http://euobserver.com/9/32658.

- $\quad$ SIPRI Military Expenditure Database, 2014, http://milexdata.sipri.org/files/?file=SIPRI+military+expenditure+database+1988-2013.xlsx.

- “Suspension of Munitions Export to PRC”, Public Notice 1109, Department of State, Office of Munitions Control, http://pmddtc.state.gov/FR/1989/54FR24539.pdf.

- Swami and Moore, 2010. "Japan Warns West against Lifting China Arms Embargo”, The Telegraph, 18 November, http://www.telegraph.co.uk/news/worldnews/asia/china/8144383/Japans-warns-West-againstlifting-China-arms-embargo.html.

- Tang, 2005. "The EU's Policy towards China and the Arms Embargo", Asia Europe Journal (3), p. 319.

- The Economist, 2010. "The EU and Arms for China", 1 February, http://www.economist.com/blogs/charlemagne/2010/02/eu_china_arms_embargo.

- Wacker, Gudrun. 2011. "The European Union and East Asian Security: Prepared for the Future?” in van der Putten, Shulong, China, Europe and International Security, New York, Routledge, p. 132. 